\title{
ESTIMATING CROP COEFFICIENTS FOR CORN DURING AN EVAPOTRANSPIRATION EXPERIMENT ON AN OXISOL IN BRAZIL
}

\author{
M.M. VILLAGRA; D. GABRIELS; H. VERPLANCKE; R. HARTMANN \\ Laboratory of Soll Physics, University of Gent, Coupure Links 653, 9000 - Ghent, Belgium. \\ K.REICHARDT \\ Department of Physics and Meteorology - ESALQ/USP - P.O.Box 9 - CEP: 13418-900 - Piracicaba,SP - Brazil
}

\begin{abstract}
Soil water balance components were measured during two periods (from 1989 to 1991) on a Dark Red Latosol (oxisol) in Piracicaba,SP, Brazil. The change in soil water storage and the soil water fluxes at the lower limit of the rooting zone were calculated for a transect of 25 observation plots. Hydraulic head gradients were determined by tensiometer measurements. Soil water flux densities were estimated through Darcy's equation. The actual evapotranspiration of the crops and weeds and the actual evaporation of bare soil were obtained from the water balance equation and this for two periods under different crop rotations. For the first period the sequence was bare soil-corn-weeds and for the second period it was stubble mulch-weeds-com. For assessing the crop coefficients the potential evapotranspiration was calculated according to two different methods. The first method was based on the modified Penman equation with grass as a reference crop, to obtain this way reference coefficients, and the second method was based on the pan "A" evaporation data in order to obtain pan coefficients. These coefficients were compared with the tabulated crop coefficients. In general when there was no shortage of water during the corn growth, the crop coefficients $k_{c}{ }^{\prime \prime} A^{\prime \prime}$ and $k_{c}$ ref were very close to the $k_{c}$ values.
\end{abstract}

Key Words: crop coefficient, evapotranspiration, spatial variability

\section{DETERMINAÇÃo dE COEFICIENTES dE CULTURA PARA O MILHO DURANTE UM EXPERIMENTO DE EVAPOTRANSPIRAÇÃO EM UM OXISOL DO BRASIL.}

RESUMO: Os componentes do balanço hidrico foram medidos durante dois periodos (de 1989 a 1991) em terra roxa estruturada, em Piracicaba,SP, Brasil. As variaçőes de armazenamento de água e os fluxos de água no solo no limite inferior da zona radicular foram calculados para uma transeção de 25 parcelas experimentais. Gradientes hidráulicos foram determinados por meio de medidas tensiometricas. Densidades de fluxo de água foram estimadas através da equação de Darcy. A evapotranspiração atual das culturas e das ervas daninhas e a evaporação atual do solo nú foram obtidas da equação do balanço hídrico, para dois períodos, sob diferentes rotaçð̄es de cultura. Para o primeiro periodo a sequência foi solo nú - milho - ervas daninhas e para o segundo cobertura morta - ervas daninhas - milho. Para determinar os coeficientes de cultura, a evapotranspiração potencial foi calculada por dois métodos. 0 primeiro foi baseado na equação de Penman modificada, com a grama como cobertura de referencia, obtendo assim os coeficientes de referência, e o segundo baseado no tanque de evaporação tipo classe " $A$ ", obtendo os coeficientes de tanque. Estes coeficientes foram comparados com os coeficientes de cultura tabulados. De uma forma geral, em periodos sem falta de água para a cultura, os coeficientes de referencia e de tanque se assemelharam bastante aos coeficientes de cultura.

Descritores: coeficiente de cultura, evapotranspiração, variabilidade espacial

\section{INTRODUCTION}

The knowledge of the interaction between rainfall and evapotranspiration processes and the resulting soil moisture regime is important since the latter is the principal factor which affects the crop productivity in tropical humid and subhumid regions. In these regions when soil water is available, the evapotranspiration can reach 10 mm.day ${ }^{-1}$ under low atmospheric humidity and high wind velocity conditions (REICHARDT, 1987).

The evaporation losses are important on bare soils, during the early stage of crop development and in row or perennial crops where the distance among the plants is large. Soil evaporation can account for as much as $50 \%$ of the 
total evapotranspiration when the soil surface is frequently wet after summer rains. The transpiration rate of well developed crops is higher than the evaporation rate from the soil. So the knowledge of these two rates representing the total water losses to the atmosphere is very important.

Due to the difficulty in measuring the meteorological factors on which evapotranspiration depends, several scientists have combined more easily measured climatic factors into simple empirical formulas. Even when they are accurate for the estimation over large areas, the disadvantage is that these equations disregard the water movements on and within the soil profile.

The most suitable method to estimate evapotranspiration by following the variation in soil moisture is the field water balance. The field water balance is an account of all quantities of water added to, substracted from, and stored within a given volume of soil during a given period of time (HILLEL, 1980). All the variables can be measured in the field except the actual evapotranspiration $\left(E T_{a}\right)$ or the evaporation $\left(E_{a}\right)$ that often is the largest component of the water balance. It is relatively easy to measure the amount of water added to the field by precipitation and irrigation, although it is necessary to consider possible nonuniformities in areal distribution. The amount of run-off generally is (or at least should be) small in agricultural fields and particularly in irrigated fields, so that it can sometimes be regarded as negligible in comparison with the other components of the water balance (HILLEL, 1980).

Soil water storage is simple to determine since the use of a neutron probe allows to follow the changes in moisture content frequently and at any depth. This instrument is recommended for soil water measurements since it allows the measurements at the same depth over long periods since the only perturbation made in the soil is the access tube installation (GARDNER, 1987).

Under field conditions a large variability in soil water storage is commonly found in replicate profiles. This is partly because of the uneven wetting of the soil during rain and partly because of non-uniform losses by drainage and root extraction. This variability requires attention to replication and location of access tubes when assessing the evapotranspiration for a particular site (McGOWAN \& WILLIAMS, 1980).

The soil water losses due to drainage and evapotranspiration are the most difficult components of the water balance to quantify separately, since generally they require specialized instrumentation and intricate techniques that do not always offer improved accuracy. Many authors have presented methods to estimate and separate these two variables. The field capacity method, which held that downward flow or drainage virtually ceased after two or three days, has been succesfully used by DAY et al, (1978) and FRANCIS \& PIDGEON (1982a). Nevertheless, the downward flow out of the root zone (drainage) is not always negligible and often constitutes $20 \%$ or more of the field water balance even under a normal water regime (REICHARDT et al.,1974). Some drainage is essential in irrigated agriculture sometimes, particularly in arid regions to prevent salinization in the root zone. Excessive drainage is also undesiderable since it might leach nutrients out of the root zone. It means that movement below the root zone can be important in the field water balance and thus has to be measured and controlled (HARTMANN, 1990).

As the determination of the evapotranspiration by the water balance method depends on hydrodynamical soil properties that vary in space and time, consequently the average in evapotranspiration of several replications in the field might be affected by these variations.

The aim of the present study were to determine the values of the hydrological parameters such as soil water storage, soil moisture content, soil matric head, unsaturated hydraulic conductivity that characterize field capacity condition along a $125 \mathrm{~m}$ transect.

The calculation of the evapotranspiration values for each plot of the transect of $125 \mathrm{~m}$, by using the water balance equation and the comparison of these values through different soil covers in terms of spatial variation (standard deviations) and temporal variation (average values).

A comparison is also made between the experimental values of potential evapotranspiration obtained from the evaporation pan "A" (ET $T_{0}$ "A") and the calculated values from the Penman method (ET, ref) and also with the corn coefficients $\left(k_{c}\right)$ in order to compare the different conditions during the corn development for two consecutive growing periods.

\section{MATERIALS AND METHODS}

The experiment was carried out in Piracicaba, SP, Brazil, located in the tropics, 
$22^{\circ} 44^{\prime} \mathrm{S}$ and $47^{\circ} 33^{\prime} \mathrm{W}$, at an altitude of $580 \mathrm{~m}$ above sea level and $250 \mathrm{~km}$ inside the continent. The soil studied is a Red Latosol, known as "Terra Roxa Estruturada"(Brazilian System) and classified as a Rhodic Kandiudalf according to the Soil Taxonomy Classification. According to the USDA Classification Scheme this soil can be classified as clayey for presenting more than $60 \%$ of clay in all the horizons. The choice of $150 \mathrm{~cm}$ depth as the lower limit of the rooting zone was due to the observation of the absence of roots at this depth (MENESES LÔBO, 1984).

According to Köppen's classification the climate is Cwa, what means mesotermic subtropical humid with dry winter. The mean temperature of the coldest month is less than $18^{\circ} \mathrm{C}$ and that of the warmest month more than $22^{\circ} \mathrm{C}$. The typical rainy season is from October to March and the dry season is from April to September. The average annual rainfall is $1,247 \mathrm{~mm}$ and the average temperature is $21.1^{\circ} \mathrm{C}$.

Measurements of the water balance components were carried out during 1990-1991 to calculate $\mathrm{ET}_{\mathrm{a}}$ or $\mathrm{E}_{\mathrm{a}}$ using the equation:

$$
\begin{aligned}
E T_{a}\left(\operatorname{OI~} E_{\mathrm{a}}\right) & =P+I+Q_{150}+ \\
& +R+\Delta S_{150}
\end{aligned}
$$

where $\Delta S_{150}(\mathrm{~mm})$ represents the change in soil water storage in the layer $0-150 \mathrm{~cm}$ during the period $\Delta t$, measured twice a month with a neutron probe (Nardeux, SOLO-25), calibrated at the same field site; $P(\mathrm{~mm})$ the rainfall during $\Delta \mathrm{t} ; \mathrm{I}(\mathrm{mm})$ the irrigation during $\Delta t ; \quad E T a(m m)$ the actual evapotranspiration during $\Delta t$ and $\mathrm{Ea}(\mathrm{mm})$ the evaporation from the bare soil during $\Delta t ; Q_{150}$ $(\mathrm{mm})$ the soil water fluxes that are the result of the integration of soil water flux densities $q_{150}$ at the lower soil boundary $(\mathrm{z}=150 \mathrm{~cm})$, also during $\Delta \mathrm{t}$; and $R$ the run-off contribution over $\Delta t$.

The change in soil water storage $\Delta \mathrm{S}_{150}$ and the drainage $Q_{150}$, were calculated from the data collected on a transect of 25 observation plots $(5 \times 5 \mathrm{~m})$ located accross the experimental field, as shown in Figure 1.

Each observation point per plot had one aluminium access tube for neutron probe measurements, two mercury manometer tensiometers installed at the depths of 135 and 165 $\mathrm{cm}$, in order to estimate the hydraulic head gradients $(\nabla \mathrm{H})$ at $150 \mathrm{~cm}$. The hydraulic head $\mathrm{H}$
$(\mathrm{kPa})$ is assumed as the sum of matric $\mathrm{h}(\mathrm{kPa})$ and gravitational $\mathbf{z}(\mathrm{kPa})$ heads.

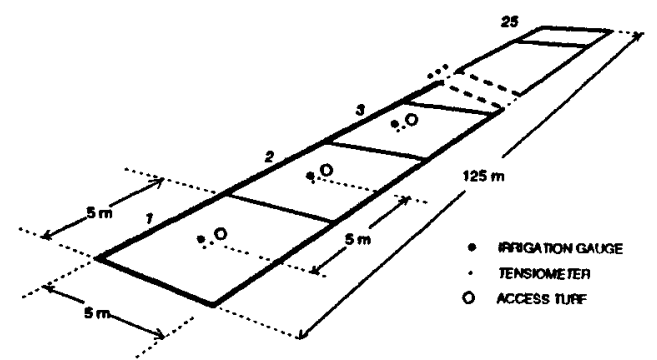

Figure 1. Schematic representation of the transect with 25 observation plots.

Soil water flux densities $\mathrm{q}_{150}\left(\mathrm{~mm} \cdot\right.$ day $\left.^{-1}\right)$ were estimated through Darcy's equation:

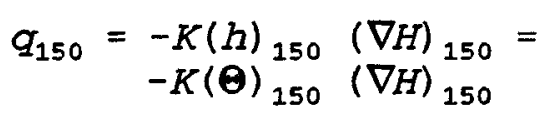

Where $\mathrm{h}(\mathrm{kPa})$ is the average matric head for the depths 135 and $165 \mathrm{~cm}$, representing the $150 \mathrm{~cm}$ depth; and $\theta\left(\mathrm{cm}^{3} . \mathrm{cm}^{-3}\right)$ the soil water content at $z=150 \mathrm{~cm}$. For each plot, the $K(h)_{150}$ and $K(\theta)_{150}$ functions were established by performing an internal drainage test as described by HILLEL et al.(1972). Details of the procedures used to evaluate these functions are described in VILLAGRA (1991). The total hydraulic head gradients were estimated according to:

$$
(\nabla H)_{150}=\frac{\left(H_{135}-H_{165}\right)}{30}
$$

Soil water storage $S_{L}(\mathrm{~mm})$ was obtained using Simpson's integration rule (HAVERCAMP et al., 1984):

$$
\begin{aligned}
& S_{L}=1 / 3\left[\Theta_{0}+4 \Theta_{25}+2 \Theta_{50}\right. \\
& \left.+4 \Theta_{75}+2 \Theta_{100}+4 \Theta_{125}+\Theta_{150}\right]
\end{aligned}
$$

where the subcripts of the soil water content $\theta$ indicate the depth of the measurement. Since no surface measurements were made, $\theta_{0}$ was assumed to be equal to $\theta_{25}$, and $\Delta \mathrm{z}$ is equal to $25 \mathrm{~cm}$. 
Rainfall was measured at a weather station located $200 \mathrm{~m}$ from the site. Irrigation has to be measured at each plot because of the uneven water distribution of the sprinklers. Runoff was not measured directly because the transect covers an almost leveled field.

During the two studied periods, $(12 / 6 / 89-23 / 3 / 90)$ and $(5 / 7 / 90-14 / 3 / 91), 17$ water balances were calculated for each plot, under different sequences of soil covers: for the first period the sequence was bare soil-corn crop-weeds and for the second period the studied sequence was stubble mulch-weeds-com crop. Between these two periods the internal drainage experiment for each plot of the transect was performed from $29 / 5 / 1990$ to $15 / 6 / 1990$.

The actual evapotranspiration ( $\mathrm{ET}_{\mathrm{a}}$ ) for each point was calculated through the water balance (equation 1). In order to determine the potential evapotranspiration (ET ${ }_{0}$ " $A$ ") for all the studied periods, one class " $A$ " evaporation pan was installed near the plot number 1 . These evaporation measurements were multiplied by the pan coefficient (kp) (DOORENBOS \& PRUITT, 1977) according to the meteorological data of the region (wind speed and relative humidity) and the different covers of the soil surface.

Potential evapotranspiration (ET $\mathrm{T}_{0}$ ref) was also estimated through the modified Penman equation as described by Doorenbos and Pruitt (1977), for grass as the reference crop, and called here ETref. Calculations were made with the help of a computer package for calculating crop water requirements (RAES et al., 1986), using daily meteorological data of the region: namely minimum and maximum temperature, hours of sunshine, average relative humidity, wind speed at $2 \mathrm{~m}$ height and rainfall.

Finally, relating the mean values of the $\mathrm{ET}_{\text {a }}$ to $\mathrm{ET}_{0}$ "A", or to $\mathrm{ET}_{0}$ ref (by the $\mathrm{ET}_{\mathrm{a}} / \mathrm{ET}_{0}$ "A" $^{\prime \prime}$ and $E_{\mathrm{a}} / \mathrm{ETref}$ ratios), the crop coefficients $k_{c}{ }^{\prime \prime} A^{\prime \prime}$ and $k_{c} r e f$ for the two corn crop periods were obtained. Comparison was made among these two coeffiecients and the $\mathrm{k}_{c}$ tabulated values for the two corn periods.

\section{RESULTS AND DISCUSSION}

\section{Field Capacity Determination}

As a consequence of the experimental conditions in which the internal drainage experiment was carried out over the transect, several days after the measurements finished, the soil surface still presented a thick layer of mulch. During the following water balance period (from $14 / 6 / 1990$ to $5 / 7 / 1991$ ), a low amount of rainfall was observed $(18 \mathrm{~mm})$. No changes in soil water storage were registered within the first $50 \mathrm{~cm}$ layer due to the restricted evaporation (Figure 2). Therefore, it can be assumed that the rainfall evaporated from the mulch.

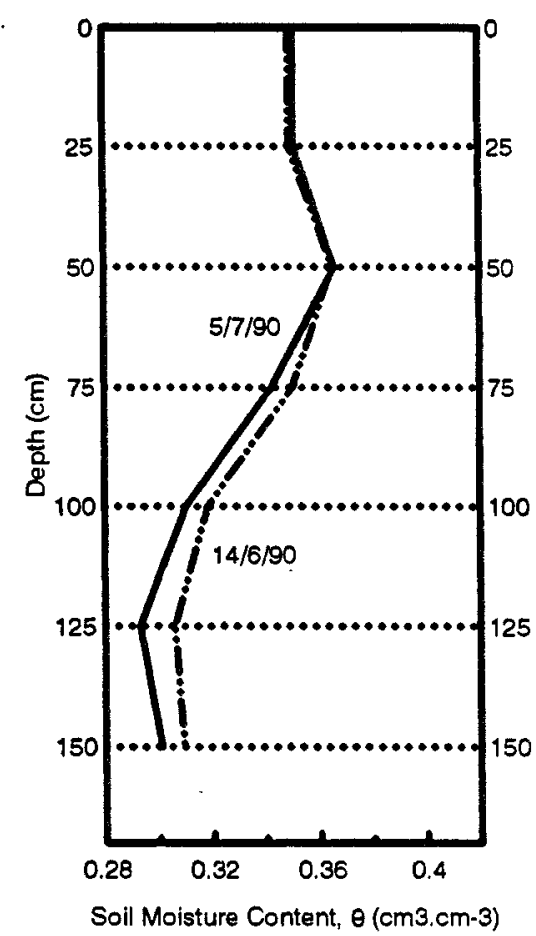

Figure 2. Average soil water content profiles of the 5 plots on $14 / 6 / 1990$ and $5 / 7 / 1990$.

In the same figure a small decrease in soil water storage can be observed caused by deep drainage out of the root zone. The flux densities varied from $0.386 \mathrm{~mm} /$ day to $0.135 \mathrm{~mm} /$ day. In this dynamic hydrological condition in which the rate of downward flux decreased significantly many days after the internal drainage process started and there was no upward movement, the water stored in the soil profile reached the field capacity condition. The values of the hydrological parameters measured at that date $(5 / 7 / 1990)$ are presented in TABLE 1, from which it can be appreciated that the mean value of matric head of the 25 plots was about $-20 \mathrm{kPa}$ with a very low deviation of the mean $(1.2 \mathrm{kPa})$. This average 
agrees with the values found for the same soil by REICHARDT (1988). The soil water storage in the $150 \mathrm{~cm}$ layer,for this condition, reached 495.9 $\mathrm{mm}$.

\section{2. $\mathrm{ET}_{\mathrm{a}}$ and $\mathrm{E}_{\mathrm{a}}$ determinations through the Water Balance}

2.1. First Period: The actual evapotranspiration $\left(\mathrm{ET}_{\mathrm{a}}\right)$ in case of crops and weeds and the actual evaporation $\left(\mathrm{E}_{\mathrm{a}}\right)$ for bare soil were obtained using equation (1). The daily water flux densities $q_{150}$ between two consecutive water storage determinations $S_{L}$, were integrated in order to obtain the deep drainage $Q_{150}$. These values and the difference in soil water storage $\Delta S_{150}$ were substracted from the irrigation $P$ or the rainfall to obtain the unknown value of the water balance equation (ET, or $E_{2}$ ).

The value of soil water storage at field capacity was compared with the average value of soil water storage at each water balance calculation (Figure 3).

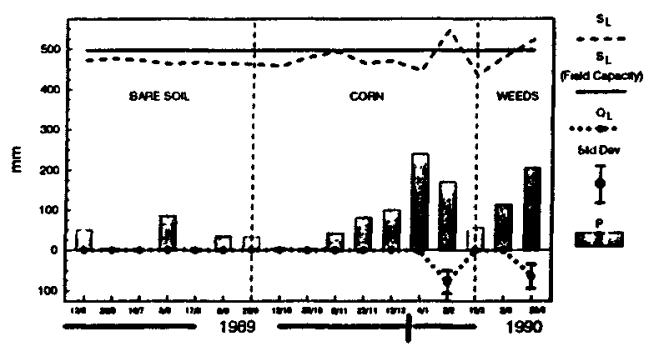

Figure 3. Temporal variation of rainfall, deep drainage $\left(Q_{L}\right)$ and soil water storage $\left(S_{\downarrow}\right)$ related with field capacity mean value of the transect. (Period 1989 1990).

This figure also shows the variation in time of rainfall, the mean values of deep drainage and the correspondent range within one standard deviation, under a sequence of soil covers, are also shown. During winter time when the soil was bare the water storages were lower than the field capacity value. There were no deep drainage $\left(Q_{150}\right)$ registered during the whole period. Therefore, the rainfall evaporated directly from the soil surface. The spatial variation of evaporation values was very low. In October (Spring) there were increments of storage till field capacity and no deep drainage was observed. During the corn development period the high water demands of the crop were supplied by the water stored in the soil and by the precipitation. As a consequence of the high rainfall registered in January 1990 (Summer) there was an increase in water storage that supplied the evapotranspiration demands and also produced a large peak of drainage $\left(Q_{150}\right)$ of about $79 \mathrm{~mm}$ with a large spatial variation of about $28 \mathrm{~mm}$. The reduction of the rainfall and the water required for weed growth caused a decrease in water storage, but afterwards again the increase in rainfall promoted an amount of water storage above field capacity. The excess of water drained out of the root zone with a mean value of about $65 \mathrm{~mm}$ and with a large spatial variation, of about $30 \mathrm{~mm}$.

The resulting evaporation $\left(E_{a}\right)$ and evapotranspiration $\left(E T_{a}\right)$ rates within the same period are presented in Figure 4. The average $E_{a}$ rate from the bare soil achieved more than 2 $\mathrm{mm} /$ day with a small variation since the calculation only depended on the change in soil water storage and on the rainfall. During the corn cycle the increasing rate of evapotranspiration decreased abruptly when the high water demands at tasseling and silking stage were not satisfied by the low rainfall. The maximum average evapotranspiration $\left(\mathrm{ET}_{\mathrm{a}}\right)$ rate $(7 \mathrm{~mm} /$ day) occured during maturity stage with a large spatial variation $(1 \mathrm{~mm} /$ day) since the calculation is based on the rainfall, the change in storage and the deep drainage, the last one showing a large variation.

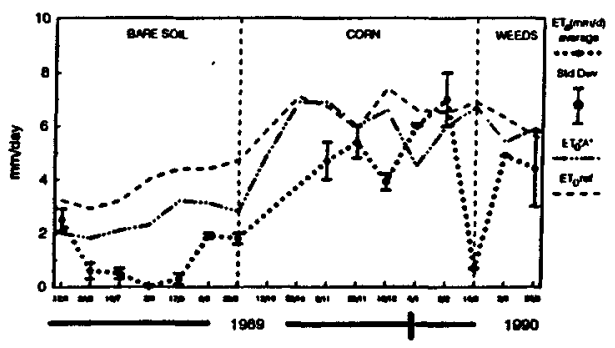

Figure 4. Temporal variation of ET (mean and standard deviation) (Period 1989 - 1990).

Another important peak of $4.4 \mathrm{~mm} /$ day with a large spatial variation of $1.4 \mathrm{~mm} /$ day, corresponded to the subsequent weed growth, associated with a large variation of the deep drainage. It is also noticeable that weeds caused high evapotranspiration rates comparable with the evapotranspiration rates of com during its early development stage. 
TABLE 1 - Hydrological parameter values at field capacity (5/7/1990).

\begin{tabular}{|c|c|c|c|c|}
\hline Hydrological Parameters & $\begin{array}{l}\text { Depth } \\
(\mathrm{cm})\end{array}$ & Mean & Std Dev & $\begin{array}{l}\mathrm{C} V \\
(\%)\end{array}$ \\
\hline $\begin{array}{l}\text { Matric Head } \\
\text { h }(\mathrm{kPa})\end{array}$ & 150 & -19.2 & 1.2 & 6 \\
\hline $\begin{array}{l}\text { Unsaturated Conductivity } \\
\qquad \mathrm{K}(\mathrm{h})(\mathrm{mm} / \text { day })\end{array}$ & 150 & 0.143 & 0.070 & 49 \\
\hline $\begin{array}{c}\text { Hydraulic Head Gradient } \\
\qquad \mathrm{VH}\end{array}$ & 150 & -1.005 & 0.414 & 41 \\
\hline \multirow[t]{3}{*}{$\begin{array}{l}\text { Flux Density } \\
\mathrm{q}_{\mathrm{L}} \text { (mm/day) }\end{array}$} & 150 & 0.135 & 0.071 & 52 \\
\hline & $\mathbf{0}$ & 0.351 & 0.015 & 4 \\
\hline & 25 & 0.351 & 0.015 & 4 \\
\hline Soil Water Content & 50 & 0.366 & 0.007 & 2 \\
\hline \multirow[t]{4}{*}{$\theta\left(\mathrm{cm}^{3} \cdot \mathrm{cm}^{-3}\right)$} & 75 & 0.342 & 0.007 & 2 \\
\hline & 100 & 0.310 & 0.009 & 3 \\
\hline & 125 & 0.293 & 0.007 & 2 \\
\hline & 150 & 0.301 & 0.008 & 3 \\
\hline $\begin{array}{c}\text { Soil Water Storage } \\
S_{\mathrm{L}}(\mathrm{mm})\end{array}$ & 150 & 495.9 & 5.9 & 1 \\
\hline
\end{tabular}

2.2. Second Period: The evolution in time of the different components of the water balance being rainfall, drainage fluxes $Q_{150}$ and soil water storage changes, for the second period (5/7/1990 $14 / 3 / 1990$ ) are shown in Figure 5. One can see that, in general, the increase in rainfall was related to the positive change in soil water storage and the highest drainage $Q_{150}$. There was a gain in water storage above field capacity when the ground surface was mulched or weeds covered, while important decrease in water storage occurred during the corn growing season.

Important water drainage $(29 \mathrm{~mm}$ with a standard deviation of $25 \mathrm{~mm}$ ) occurred in the first subperiod associated with the stubble mulch that allowed most of the precipitation to infiltrate under low atmospheric demands. The maximum water losses by deep drainage $\left(Q_{150}\right)$ were from $13 / 2 / 1991$ until the end of this subperiod, as a consequence of the large amount of rainfall.

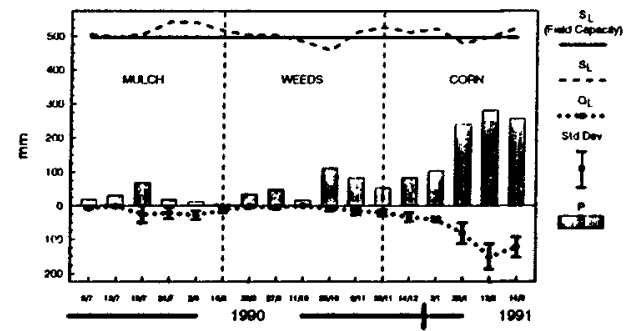

Figure 5. Temporal variation of rainfall, deep drainage $\left(Q_{L}\right)$ and soil water storage $\left(S_{L}\right)$ related with field capacity mean value of the field. (Period 1990 1991).

The water in the soil was enough for the corn development and even more important, deep drainage occurred with a maximum of $150 \mathrm{~mm}$ (standard deviation of $37 \mathrm{~mm}$ ) after tasseling and silking. 
Figure 6 shows that the variation in time of the actual evapotranspiration $\left(\mathrm{ET}_{\mathrm{a}}\right)$ rate followed the increasing trend from the beginning to the end of the period. As expected, these values were lower during the weed, corn sowing and early growth stage periods. They were higher at the end of the corn growing season, during tasseling and silking stages and again lower when the crop achieved maturity.

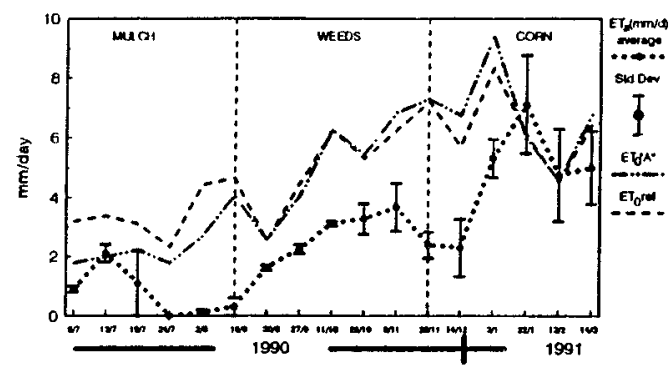

Figure 6. Temporal variation of $\mathrm{ET}_{\mathrm{a}}$ (mean and standard deviation) (Period 1990 1991).

With regard to the local variability of the $\mathrm{ET}_{\mathrm{a}}$ values, here presented as the standard deviation of the mean of the 25 points along the transect, it can be seen that these variations also increased from the beginning to the end of the period. As it was discussed formerly, the rainfall became higher from October to the end of the period, therefore there were evident increases in the deep drainage $Q_{150}$. Besides, considering that the participation of the water fluxes in the $\mathrm{ET}_{\mathrm{a}}$ determination increased, it can be assumed that the large variation of $\mathrm{ET}_{\mathrm{a}}$ calculated through the water balance equation caine from the large variations of the deep drainage over the transect.

The total water balance over the two periods showed that at the end of the first $Q_{150}$ was $200 \mathrm{~mm}$ and the rainfall about $1,400 \mathrm{~mm}$ that means $11 \%$ was lost by deep drainage while for the second period from the $1,430 \mathrm{~mm}$ of rainfall, approximately $600 \mathrm{~mm}$ were lost by deep drainage $(40 \%)$.

\section{Determination of $k_{c}$ coefficients for corn}

Crop coefficients ( $\mathbf{k}_{c}{ }^{\prime \prime} \mathrm{A}^{\prime \prime}$ and $\mathrm{k}_{\mathrm{c}}$ ref) obtained within the two corn periods were also compared with the crop coefficients $k_{c}$, proposed by DOORENBOS \& PRUITT (1977). In Figures 7 and 8 the tabulated $k_{c}$, the $k_{c} " A "$ and the $k_{c}$ ref coefficients are compared for the two corn periods. In the first, during 1989-1990, the tabulated $k_{c}$ factor shows a complete different behaviour compared to the $k_{c}$ " $A$ " and $k_{c} r e f$. The decrease of rainfall in December resulted in a decrease of $E T_{a}$ of the corn that was tasseling. Therefore, $k_{c}{ }^{n} A^{\prime \prime}$ reduced from 0.9 to 0.6 and 0.56 respectively, presenting $k c$ the same value of 1.05 for this period. Afterwards $\mathrm{k}_{\mathrm{c}}$ ref went up to 0.9 and $\mathrm{k}_{\mathrm{c}}$ " $\mathrm{A}$ " reached 1.3 during the corn dough stage while $\mathrm{kc}$ is 1.05 . This large difference was reached after many days with high rainfall that decreased the pan " $A$ " evaporation values and consequently $\mathrm{ET}_{0}{ }^{\prime} \mathrm{A}$ ". After the corn dough stage high values of $\mathrm{ET}_{\mathrm{a}}$ determined an increase of $k_{c}{ }^{\prime \prime} A$ and $k_{c}$ ref and an important decrease at maturity stage.

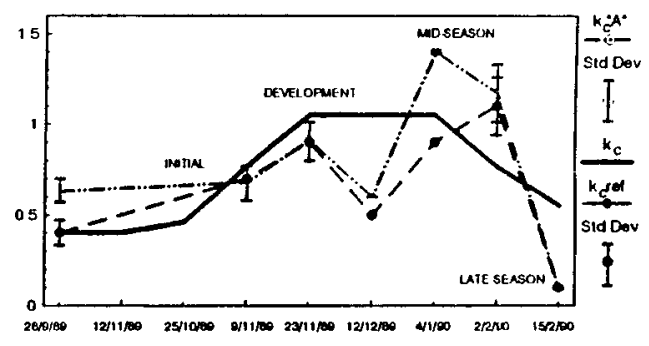

Figure 7. Crop coefficients $\mathrm{k}_{c}$ (DOORENBOS \& PRUITT, 1977), $k_{c} " A "$ and $k_{c} r e f$ (mean and standard deviation) during the corn subperiod (period 1989 - 1990).

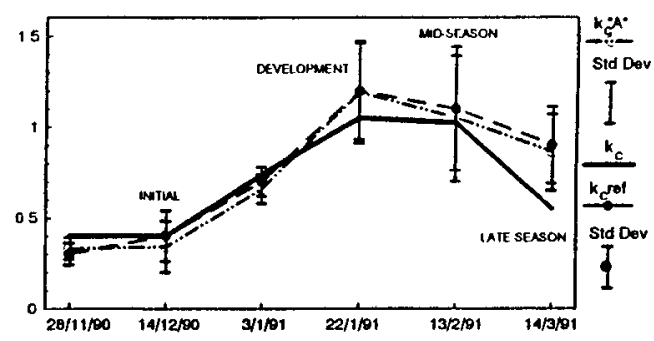

Figure 8. Crop coefficients $k_{c}$ (DOORENBOS \& PRUITT, 1977), $k_{c}{ }^{\prime} A$ " and $k_{c} r e f$ (mean and standard deviation) during the corn subperiod (period 1990 - 1991).

During the corn development in 19901991 (Figure 8), both $\mathrm{k}_{\mathrm{c}}{ }^{\mathrm{A}} \mathrm{A}$ " and $\mathrm{k}_{\mathrm{c}}$ ref coefficients were very close to the $k_{c}$ coefficient. The lowest $k_{c}$ value was found on 14/3/91, when the corn reached its full maturity. In Figure 7 it can be seen 
the small variation of the $k_{r}^{\prime \prime} A "$ and $k_{r} r e f$ coefficients as a consequence of the small variation of $\mathrm{ET}_{\mathrm{a}}$ during the first period. On the contrary Figure 8 shows that $k_{c} " A$ " and $k c$ ref presented high values of standard deviation and consequently the tabulated $k_{c}$ coefficients are included in this range. That confirms the idea that only in the second period the ideal condition for crop development was reached. Figure 8 also shows that the small spatial variation of $k_{c}{ }^{\prime \prime} A$ " and $k_{c}$ ref occurred during the initial stage of the corn and the high variation were obtained during the corn development stage. This was due to the fact that the resulting values of $\mathrm{ET}_{\text {a }}$ were affected by the variation of the deep drainage along the transect, what is in agreement with what was found by POSS \& SARAGONI (1987). In a similar study these authors found also that the maximum value of $k_{c}{ }^{\prime \prime} A$ " for corn was reached between 45 and 60 days after sowing.

\section{CONCLUSIONS}

The occurrence of deep drainage $Q_{150}$, is not only related to the high rainfall, but also to the soil water storage larger than field capacity, as well as to soil surface conditions. Exceptional high values of rainfall were registered during the month of July 1989 and July 1990, but the effect was different in both periods due to the different levels of soil water content and conditions of the soil surface. While during July 1989 the soil water storage was very low, the surface was bare and the high rainfall produced ponded water on the soil surface, in July 1990 the soil was covered with stubble mulch, presenting a high value of water storage, and the high rainfall produced a large amount of deep drainage. The total amount of drainage $Q_{150}$ represented for both studied periods $11 \%$ and $40 \%$ of the total rainfall respectively.

Data of soil water storage for this soil showed that the water available for agricultural purposes is very low. Maximum and minimum values were $432 \mathrm{~mm}$ and $565 \mathrm{~mm}$ which represent $133 \mathrm{~mm}$ of the water available for the $150 \mathrm{~cm}$ layer. Soil water storage values showed very low coefficients of variation, of the order of $3 \%$. The value of soil water storage for the $150 \mathrm{~cm}$ layer, at field capacity conditions ( $496 \mathrm{~mm}$ ) is useful in case of complementary irrigation since the drainage below $150 \mathrm{~cm}$ depth occurs when the soil water storage is larger than field capacity. For the 25 plots the average of matric head values at field capacity $(-20 \mathrm{kPa})$ was different from those found in the literature of $-1 / 10$ atm or $-1 / 3 \mathrm{~atm}$ (HILLEL,1980 and REICHARDT, 1988). These values help in the hydrological characterization of this oxisol that represents great proportion of the most fertile agricultural soils of Brazil.

The ET, mean values calculated through the water balance equation varied with the different ground covers, showing maximum values for weeds and for corn at development stage of about 7 $\mathrm{mm} /$ day. While evaporation from bare soil and from the stubble mulch presented maximal values of about $2 \mathrm{~mm} /$ day. The spatial variation of these values was from $1 \%$ to $42 \%$ during the studied periods. These coefficients extremely high indicate that the spatial variation of soil properties and processes strongly limit the use of the water balance equation under field conditions. During the two studied periods, the evolution of $\mathrm{ET}_{0}{ }^{\prime \prime} \mathrm{A}$ " and $\mathrm{ET}_{0}$ ref followed the same pattern. By using either evaporation pan " $A$ " or Penman equation, very similar $\mathrm{ET}_{0}$ values were obtained. The mean values of $k_{c}$ " $A$ " and $k_{c}$ ref were very closed to $k_{c}$ tabulated values only when no shortage of water affected the corn development. These coefficients showed the same high variation of $\mathrm{ET}_{\mathrm{a}}$ along $125 \mathrm{~m}$ transect.

\section{REFERENCES}

DAY, W.; LEGG, B.J.; FRENCH, B.K.; JOHNSTON, A.E.; LAWLOR, D.W.; JEFFERS, W.C. A drought experiment using mobile shelters: the effect of drought on barley yield, water use and nutrient uptake. Journal of the Agricultural Science, Cambridge, v.91, n.3, p.599-623, 1978 .

DOORENBOS, J.; PRUITT, W.O. Guidelines for predicting crop water requirements. Rome: FAO, 1977, 143p. (FAO: Irrigation and Drainage Paper, 24).

FRANCIS, P.E.; PIDGEON, J.D. A model for estimating soil moisture deficit under cereal crops in Britain. 1. Development. Journal of Agricultural Science, Cambridge, v.98, n.3, p.651-661, 1982a.

GARDNER, W.R. Water content: an overview. In: INTERNATIONALCONFERENCEONMEASUREMENT OF SOIL AND PLANT WATER STATUS, 1987, Logan. 1987. v.1, p.7-9.

HARTMANN, R. How to evaluate the field water balance. I. soil physics: applications under stress environments. In: SEMINAR ON SOIL PLANT RELATIONSHIPS, 1989, Islamabad, Proceedings... Islamabad: Pakistan Agricultural Research Council, 1990. p.113-124. 
HAVERCAMP, R.; VAUCLIN, M.; VACHAUd, $G$. Error analysis in estimating soil water content from neutron probe measurements. 1. Local standpoint. Soil Science, Baltimore, v.137, n.2, p.78-90, 1984.

HILLEL, D. Applications of soil physics. London: Academic Press, 1980, 385p.

HILLEL, D.; KRENTOS, V.D.; STYLIANOU, Y. Procedure and test of an internal drainage method for measuring soil hydraulic characteristics in situ. Soil Science, Baltimore, v.114, n.5, p.395-400, 1972.

McGOWAN, M.; WILLIAMS, J.B. The water balance of agricultural catchment. Journal of Soil Science, Oxford, v.31, p.217-244, 1980.

MENESES LÔBO, A.E. Relaçōes solos-superfícies fisiográficas em uma toposequiência de Piracicaba,SP. Piracicaba, 1984. 250p. Tese (Doutorado) - Escola Superior de Agricultura "Luiz de Queiroz", Universidade de São Paulo.

POSS, R.; SARAGONI, H. Some hydrological problems about the estimation of the water balance in the field. Bulletin du G.F.H.N, Angers, n.22, p.31-47, 1987.
RAES, D.; VAN AELST, P.; WYSEURE, G. ETref, ETcrop, ETsplit and deficit, a computer package for calculating crop water requirements: reference manual. Leuven: Laboratory of Soil and Water Engineering. 1986.

REICHARDT, K. A agua nos sistemas agricolas. Sao Paulo: Manole, 1987. 188p.

REICHARDT, K. Capacidade de campo. Revista Brasileira de Ciência do Solo, Campinas, v.12, n.3, p.211-216, 1988.

REICHARDT, K.; LIBARDI, P.; SANTOS, J. An analysis of soil water movement in the field. II Water balance in a snap bean crop. Piracicaba, Centro de Energia Nuclear na Agricultura, 1974. (Boletim Científico, 22).

VILLAGRA, M.M. Variation in space and time of hydrological components of the water balance. Gent, 1991. 134p. Thesis (Ph.D.) - University of Gent.

Enviado para publicação em 16.09.93

Aceito para publicação em 10.02.94 